\title{
Trends and Future Research in Electronic Marketing: A Bibliometric Analysis of Twenty Years
}

\author{
Peng Gao ${ }^{1}$, Fanchen Meng ${ }^{1, *}$, Mário Nuno Mata ${ }^{2,3}{ }^{\oplus}$, José Moleiro Martins ${ }^{2,4} \oplus^{\oplus}$, Shahid Iqbal ${ }^{5}$, \\ Anabela Batista Correia ${ }^{2}$, Rui Miguel Dantas ${ }^{2}{ }^{-}$, Abdul Waheed ${ }^{6}$, João Xavier Rita ${ }^{2}(\mathbb{D}$ and \\ Muhammad Farrukh $1,7, * \mathbb{D}$
}

Citation: Gao, P.; Meng, F.; Mata, M.N.; Martins, J.M.; Iqbal, S.; Correia, A.B.; Dantas, R.M.; Waheed, A.; Xavier Rita, J.; Farrukh, M. Trends and Future Research in Electronic Marketing: A Bibliometric Analysis of Twenty Years. J. Theor. Appl. Electron. Commer. Res. 2021, 16, 1667-1679. https://doi.org/10.3390/jtaer16050094

\section{Academic Editors:}

Eduardo Álvarez-Miranda, Shib Sankar Sana and Sweety Sadhukhan

Received: 26 March 2021

Accepted: 18 May 2021

Published: 21 May 2021

Publisher's Note: MDPI stays neutral with regard to jurisdictional claims in published maps and institutional affiliations.

Copyright: (c) 2021 by the authors. Licensee MDPI, Basel, Switzerland. This article is an open access article distributed under the terms and conditions of the Creative Commons Attribution (CC BY) license (https:// creativecommons.org/licenses/by/ $4.0 /)$.
1 School of Management and Economics, Beijing Institute of Technology, Beijing 100083, China; gaopeng596@163.com

2 ISCAL-Instituto Superior de Contabilidade e Administração de Lisboa, Instituto Politécnico de Lisboa, Avenida Miguel Bombarda, 20, 1069-035 Lisboa, Portugal; mnmata@iscal.ipl.pt or mario.mata@esg.ipsantarem.pt (M.N.M.); jmmartins@iscal.ipl.pt (J.M.M.); ambatista@iscal.ipl.pt (A.B.C.); rmdantas@iscal.ipl.pt (R.M.D.); jmrita@iscal.ipl.pt (J.X.R.)

3 School of Management and Technology (ESGTS-IPS), Polytechnic Institute of Santarém, 2001-904 Santarém, Portugal

4 Instituto Universitário de Lisboa (ISCTE-IUL), Business Research Unit (BRU-IUL), 1649-026 Lisboa, Portugal

5 MUST Business School, Mirpur University of Science and Technology, Mirpur 10250, Pakistan; shahid.mbs@must.edu.pk

6 School of Business and Economics, University of Management and Technology, Lahore 54770, Pakistan; abdulwaheed168@yahoo.com

7 Department of Business Administration, Ilma University, Karachi 75190, Pakistan

* Correspondence: meng@bit.edu.cn (F.M.); mfarrukhiqbal@hotmail.com (M.F.)

Abstract: Electronic marketing $(\mathrm{eM})$ is a flourishing phenomenon that is gaining intense concern because of a significant impact on organizational performance. Over the past few decades, the relevance of eM has been observed in numerous fields (e.g., consumers, organizational strategy, advertisement, and overall philosophy of management to understand the insights globally). To effectively maneuver the field, all stakeholders, particularly academicians and practitioners, must comprehend the current position of the eM theory and practices for dynamic utilization. A systematic bibliometric analysis can serve this issue by providing a holistic view of the publication trend and its trajectory in terms of various themes, including citations and publication metrics. This study analyzes the bibliometric data from 2000 to 2019 to reveal the most productive countries, universities, authors, journals, and prolific publications in electronic marketing. To this end, VOS viewer software was used to visualize the mapping based on co-citation, bibliographic coupling (BC), and co-occurrence (CC). The primary addition of this research is to provide an overview of eM tendencies and paths that may help researchers know the tendencies and future research directions worldwide.

Keywords: electronic marketing; bibliometric analysis; co-occurrence; bibliographic coupling

\section{Introduction}

Electronic marketing (eM) is a mechanism to convey knowledge about a product by the medium of the internet [1]. Electronic marketing remains a developing system which provides such a terrace, which made it possible to run all types of electronic promotions through internet-oriented technologies [2]. Brodie et al. [3] declared e-marketing an origin of communication between customers and organizations by using communication technologies. In a previous research study [4], the model consisted of distinctive marketing observations such as interaction marketing, database marketing, transaction marketing, and network marketing. After quite some time, Coviello et al. [4] also branded a novel element of promotion actions that is recognized as e-marketing. Afterward, the investigators concentrated on the research of electronic marketing in diverse frameworks and magnitudes [5]. 
In the last couple of years, the research on electronic and digital marketing has seen immense growth [6,7]. Several researchers have conducted empirical examinations on different internet-based promotional mediums, including mobile marketing [8] network marketing [3], intranet marketing [9], digital marketing [10], and internet marketing [11]. Studies on electronic marketing, especially with consideration of bibliometric analysis, are missing in the literature, which is the unique contribution of this article. Therefore, to effectively understand and steer any academic field such as electronic marketing, practitioners and academicians must be aware of the current trends and trajectories of any field.

The field of studies concerned with the quantitative investigation of the published literature is called bibliometrics $[12,13]$. Bibliometric studies are now widely used in a wide range of academic disciplines, including management, economics, accounting, consumers, promotions, and entrepreneurship. Previous research has looked at a number of subjects, such as the publishing patterns in a particular journal [14], the most cited papers [15], leading authors [16,17], journals [18], and universities [19]. However, to the best of our knowledge, this study is the first that attempts to conduct a bibliometric analysis for electronic marketing research since the very first publication was recorded in the Scopus database.

The main contribution of this study is that it provides a broad overview of the leading countries, universities, journals, and authors, as well as the most cited papers and future research agendas for electronic marketing research. It is imperative for journal editors to know the places where growth is possible for the discipline. Potential scholars may also gain value from this investigation because they may get an overall picture of areas that are strongly investigated so they can find satisfactory places to follow a graduate program. Policymakers may be concerned with this method in the direction of recognizing the foremost countries in electronic marketing studies. The research can also offer global companies with a more profound understanding of the best environments for the directive of installing their R\&D centers.

We took a similar approach to [20] in this report, but with an emphasis on e-marketing research, which is a relatively new subject compared with innovation and has received far less attention from academic researchers in terms of bibliometric review. The scope of this current study is wider, and it aims at identifying the most active countries, universities, journals, and writers of electronic marketing, taking into account many bibliometric indicators as follows.

First, this report offers a trend of publications and references between 2000 and 2019. Second, a global perspective analyzes the nations with certain numbers of articles and citations. Third, the most productive institutions of higher education are registered. Fourth, the journals are recognized. Fifth, the most productive authors are recognized based on the number of publications and references in relation to electronic marketing investigation. The research involved bibliometric connection and co-citation examination to understand how these journals, countries, and authors were connected. Finally, to identify the most common keywords occurring in electronic marketing, the study conducted co-occurrence analysis of the keywords. In addition, based on the analyses of the statistics acquired, we also propose a certain forthcoming investigation schedule for electronic marketing investigation.

\section{Methods}

\subsection{Brief Overview of the Bibliometric Technique}

The study of previous research is critical to the advancement of any academic area [21,22]. Certain techniques, such as qualitative literature reviews and quantitative literature reviews, can be used to synthesize the previous literature. Meta research and science mapping are examples of quantitative analysis that provide an objective view of the existing literature. Science mapping uses bibliometric techniques to examine how various areas, disciplines, individual articles, and authors are connected to one another. It gives the results a spatial presentation in the form of maps. The primary goal of science mapping 
or bibliometric analysis is to depict the intellectual framework of a research field using various factors, such as papers, writers, journals, terms, and countries. In comparison with narrative literature reviews, this method is more objective and comprehensive. Quantitative review of the literature is helpful in synthesizing the literature because it gives readers a more objective, unbiased perspective.

The bibliometric technique has gained a lot of interest from researchers in the current era due to the proliferation of computerization and easily accessible bibliographic data from databases such as the Web of Science and Scopus databases. Recently, bibliometric approaches have been used to perform bibliometric analyses of journals [23-25], disciplines [26,27], institutes, and countries [28].

We used two main aspects of bibliometric research in this review.

Performance and science mapping are two aspects of bibliographic data that are used in bibliometric methods. Science mapping visualizes the field's structure and dynamics, while performance analysis measures the productivity and effect in terms of the number of publications and citations. We attempted to include the following analysis in order to achieve the aim of our research:

- Citation and co-citation analysis;

- Bibliographical coupling;

- Keyword co-occurrence analysis.

Citation data are used in citation, co-citation, and bibliographic coupling to assess impact and similarity. Citation analysis helps to determine the journal's, paper's, or author's effect and influence, while co-citation analysis is a measure of correlation that arises when two documents receive citations from a third document. When two documents are co-cited, it is assumed that their material is identical. When two separate documents quote the third document in their reference lists, this is known as bibliographic coupling. The number of common sources between two published documents is used by $\mathrm{BC}$ to determine the degree of similarity. The greater the number of mutual references, the greater the resemblance.

\subsection{Database}

The electronic marketing research publications were found using the Scopus database. One of the most comprehensive peer-reviewed research repositories in the social sciences is Scopus. For analytical and quantitative analysis, the repository is often used and acknowledged (Donthu et al., 2020). We used the following search query: "((TITLE-ABS-KEY ("Electronic Marketing") OR TITLE-ABS-KEY("e-marketing”)) AND PUBYEAR > 1999 AND PUBYEAR < 2020)". Only "articles", conference papers, book chapters, and review documents were chosen, whereas the source type was limited to journals, books, conference proceedings, and book series. It is pertinent to mention that the documents were limited to the fields of business, management, and accounting.

The collected data was analyzed using bibliometric techniques. Bibliometrics is a branch of library and information science that uses quantitative methods to study bibliometric data [29]. Previous studies [12,30] used this technique to identify and analyze the general pattern of a particular topic, such as a journal, research area, or region. Bibliometric studies have been used in the literature to assess the importance of a topic [20] and the contributions of journals [31,32], and nations [33].

This work employed the VOS viewer program to create a visual representation of the bibliographic content [34]. The VOS viewer takes bibliographic data as an input and outputs it as graphs. Numerous bibliometric techniques were employed in this analysis, including the BC, co-citation, and co-occurrence of author keywords. $\mathrm{BC}$ happens when two documents cite the same third document [35] (i.e., studies A and B commonly cite study C). The term "co-citation" [36] refers to the occurrence of two papers being cited by the same third article (i.e., studies A and B receive a citation from study C). Additionally, co-occurrence of keywords is used to determine the keywords appearing more often in the same documents. As with the preceding notable bibliographic studies [23], this review 
employed $\mathrm{BC}$ for authors and institutions and co-citation for documents and articles. The co-occurrence of keywords was used to categorize them into broad categories.

\section{Results}

\subsection{Publication Trends}

Figure 1 offers the outcomes of the publication tendencies in electronic marketing investigation. The exploration statistics show a total of 438 papers, as well as these papers' 6173 citations. Table 1 supplements the outcomes of Figure 1.

\section{Documents by year}

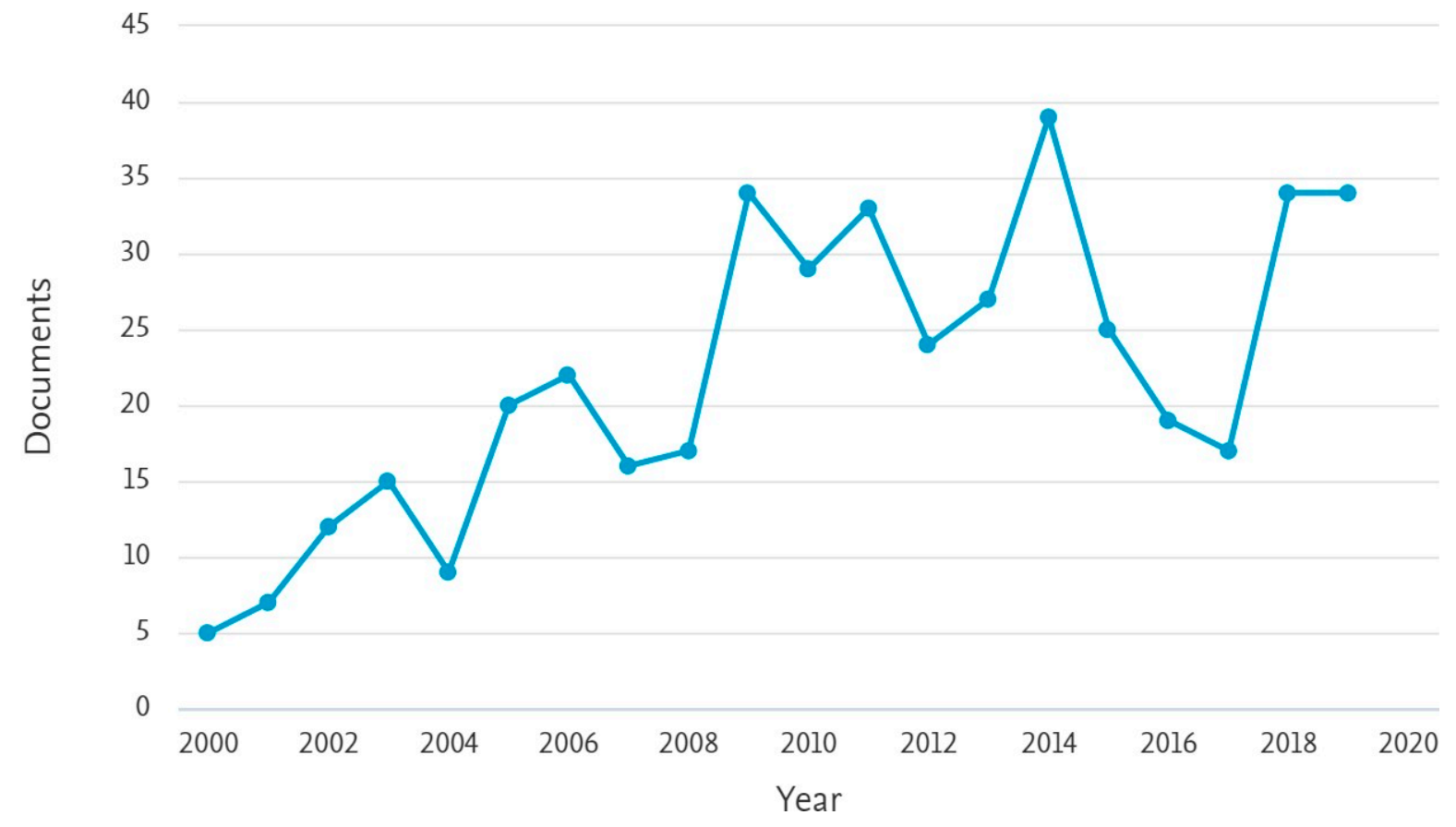

Figure 1. Trends of publications.

Table 1. Trends of publication.

\begin{tabular}{cccc}
\hline No. & Year & Publications & Citations \\
\hline 1 & 2019 & 34 & 864 \\
2 & 2018 & 34 & 758 \\
3 & 2017 & 17 & 732 \\
4 & 2016 & 19 & 607 \\
5 & 2015 & 25 & 590 \\
6 & 2014 & 39 & 511 \\
7 & 2013 & 27 & 422 \\
8 & 2012 & 24 & 347 \\
9 & 2011 & 33 & 305 \\
10 & 2010 & 29 & 249 \\
11 & 2009 & 34 & 194 \\
12 & 2008 & 17 & 193 \\
13 & 2007 & 16 & 115 \\
14 & 2006 & 22 & 98 \\
15 & 2005 & 20 & 93 \\
16 & 2004 & 9 & 57 \\
17 & 2003 & 15 & 26 \\
18 & 2002 & 12 & 11 \\
19 & 2001 & 7 & 1 \\
20 & 2000 & 5 & 0 \\
\hline
\end{tabular}


The outcomes in Table 1 display that 2019 was the most prolific year, with 34 papers as well as 864 citations. This evidence shows that electronic marketing investigation is taking off. Nevertheless, the ratio was gentle and matched that of similar subjects in business management.

\subsection{Leading Countries in Electronic Marketing Research}

Several countries are publishing significant studies on electronic marketing. In this section, we look into the output and effect of the most prominent countries between 2000 and 2019. Table 2 offers the outcomes of the top 10 nations' publications in electronic marketing exploration. The position was based on the number of papers. In the case of a tie, the country with the most recent publication was ranked higher.

Table 2. The most productive countries and regions.

\begin{tabular}{cccc}
\hline Rank & Country/Region & Publications & Citations \\
\hline 1 & United States & 118 & 2788 \\
2 & United Kingdom & 50 & 899 \\
3 & India & 27 & 90 \\
4 & Australia & 26 & 220 \\
5 & China & 25 & 384 \\
6 & Greece & 24 & 428 \\
7 & Iran & 14 & 147 \\
8 & Canada & 12 & 694 \\
9 & Taiwan & 11 & 289 \\
\end{tabular}

Table 2 displays that the USA was the most productive nation, with 118 papers and 2788 citations of these publications. This shows that US academicians are paying more attention to electronic marketing as a marketing strategy. The UK was ranked second with 50 publications and 599 citations of these publications, followed by India with 27 publications and 90 citations of these publications. Likewise, Australia consists of 26 publications and 220 citations and ranked fourth in electronic marketing, while China consisted of 25 publications and 384 citations and was ranked fifth. Greece consisted of 24 publications and 428 citations and was ranked sixth, Iran consisted of 14 publications and 147 citations and was ranked seventh, Canada consisted of 12 publications and 694 citations and was ranked eighth, Taiwan (China) consisted of 11 publications and 289 citations and was ranked ninth, and finally, Jordan consisted of 10 publications and 107 citations and ranked tenth in the electronic marketing field.

Figure 2 signifies the outcomes of the bibliometric connection. Each ring indicates a nation, and the size of the ring signifies the productivity; the greater the size, the more productive they were. The UK was the most prolific nation in the terms of bibliographic coupling. It is apparent it would have the greatest, most noteworthy bibliometric connection with additional nations.

In the case of the nations, Figure 3 shows the co-authorship association. Remember that with the co-author, we could understand the scale of a country's publications and its key partnerships with other countries. The figure reflects a separate color to show the networking of the co-authorship. The United States had close cooperation with Taiwan, Turkey, and Germany, while the United Kingdom had strong partnerships with Australia, Spain, and Greece. China had strong co-authorship with France. 


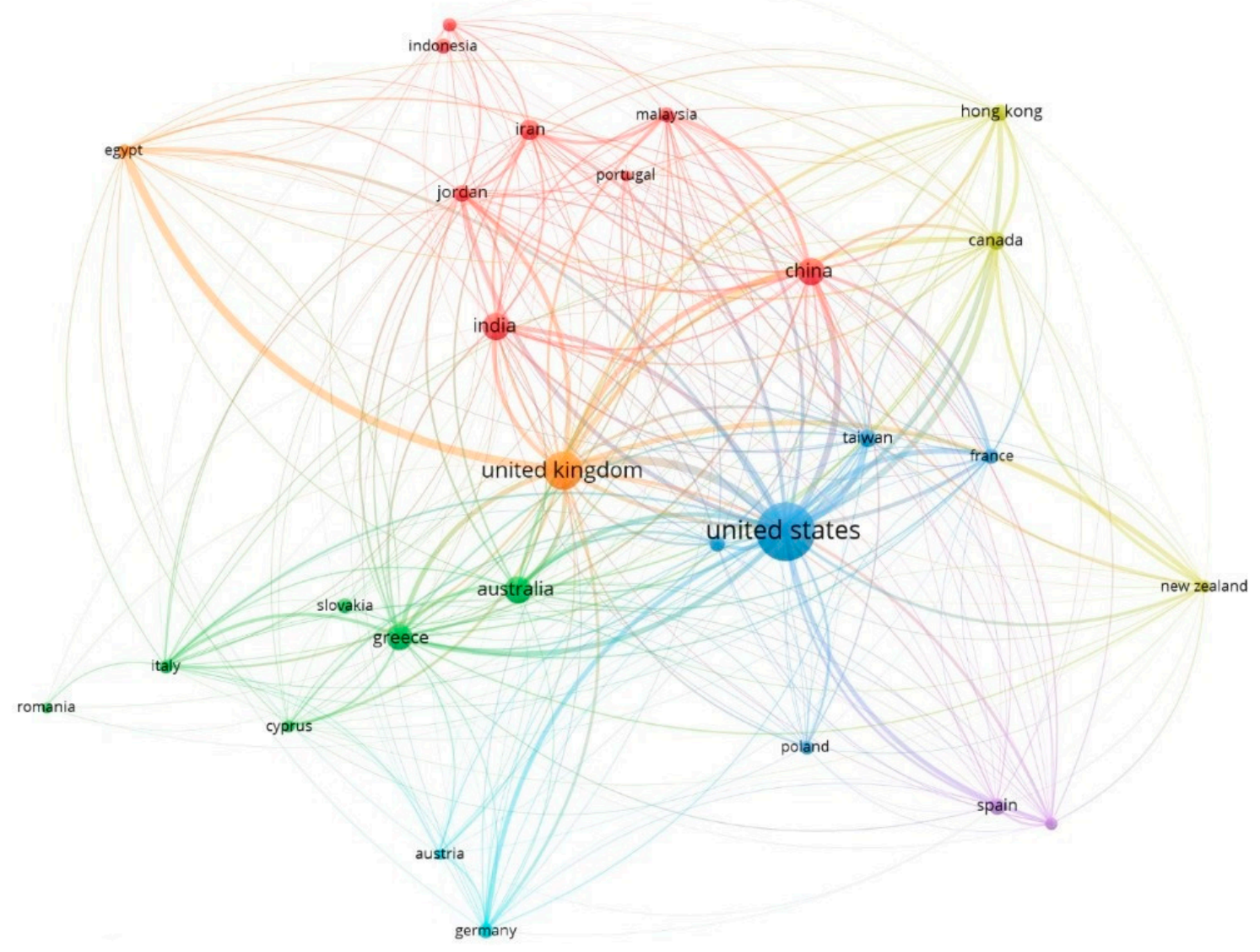

Figure 2. Bibliographic coupling of countries.

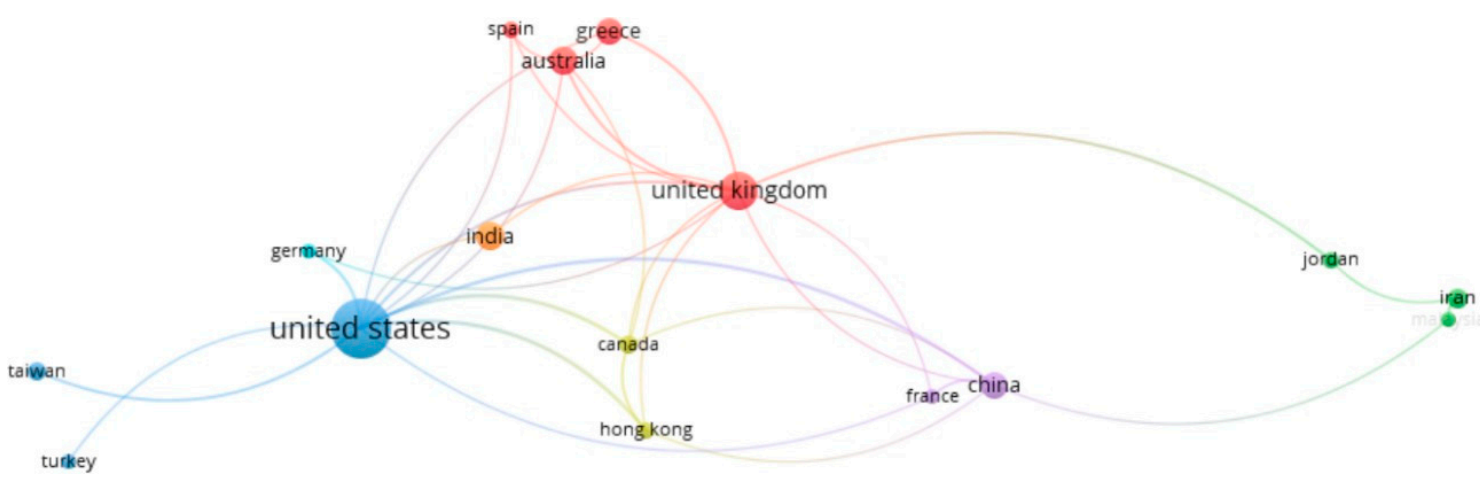

Figure 3. Co-authorship among countries.

\subsection{The Most Productive Institutes and Universities}

One of the more important aspects of the bibliometric analysis was to see which universities were the most prolific. The outcomes in Table 3 display that Panepistimion Makedonias was the most productive university. Deakin University ranked second, and the University of South Africa ranked third, followed by Cairo University and Birmingham City Business School. The University of Auckland, Lingnan University, Hong Kong, and Aristotle University of Thessaloniki followed closely. 
Table 3. The ten most productive universities.

\begin{tabular}{cccc}
\hline Rank & University/Institute & Publications & Citations \\
\hline 1 & Panepistimion Makedonias & 8 & 172 \\
2 & Deakin University & 6 & 74 \\
3 & University of South Africa & 5 & 1 \\
4 & Cairo University & 5 & 15 \\
5 & Birmingham City Business School & 5 & 184 \\
6 & University of Auckland & 4 & 203 \\
7 & Lingnan University, Hong Kong & 4 & 294 \\
8 & Aristotle University of Thessaloniki & 4 & 65 \\
9 & Erasmus Universiteit Rotterdam & 4 & 86 \\
10 & Southern Illinois University Carbondale & 4 & 7 \\
\hline
\end{tabular}

\subsection{Leading Journals}

Another essential part of the bibliometric review was to look at the most active sources (i.e., sources that conducted more electronic marketing research than others). The top ten sources that published electronic marketing research are listed in Table 4. The International Journal of Electronic Marketing and Retailing was the top journal, with 48 publications between 2000 and 2019. The International Journal of Internet Marketing and Advertising and Marketing Intelligence and Planning were second with nine publications each. Following them, the Asia Pacific Journal of Marketing and Logistics and Journal of Internet Commerce were ranked third with six publications each, while Advances in Electronic Marketing, with four publications, was the least productive source on the list.

Table 4. Top ten sources that published electronic marketing research.

\begin{tabular}{clc}
\hline Rank & \multicolumn{1}{c}{ Source } & Publications \\
\hline 1 & International Journal of Electronic Marketing and Retailing & 48 \\
2 & International Journal of Internet Marketing and Advertising & 9 \\
3 & Marketing Intelligence and Planning & 9 \\
4 & Asia Pacific Journal of Marketing and Logistics & 6 \\
5 & Journal of Internet Commerce & 6 \\
6 & Marketing and Consumer Behavior: Concepts, Methodologies, & 6 \\
7 & Tools, and Applications & 6 \\
8 & Proceedings of the International Conference on Electronic & 5 \\
9 & Business ICEB & 5 \\
10 & African Journal of Hospitality Tourism and Leisure & 5 \\
\hline
\end{tabular}

An interesting aspect of the bibliometric analysis was the co-citation analysis of the top journals. Co-citation happens when two papers from two dissimilar journals are cited together by a third document. The papers published in the above top 10 sources possessed heavy co-citation connections with each other. Table 5 endorses the results presented in Figure 4 . The results predict that an article published in the top 10 journals would be cited within the articles published in the journals mentioned in Table 5. The Journal of Marketing had 399 citations, the Journal of Business Research had 251 citations, the Journal of Marketing Research had 668 citations, the Journal of Marketing Research had 324 citations, the Journal of Business Research had 276 citations, the Journal of Retailing had 188 citations, the Journal of The Academy of Marketing Science had 179 citations, the Journal of the Academy of Marketing Science had 258 citations, the European Journal of Marketing had 214 citations, and the Journal of Travel \& Tourism Marketing had 199 citations. It is pertinent to mention that the journals sharing the same colors (Figure 4) had the strongest co-citation links. For example, the journals presented in the red color cluster were strongly co-cited, and the same applies to the other color clusters' journals. 
Table 5. Co-citation of the top ten journals.

\begin{tabular}{clcc}
\hline No. & \multicolumn{1}{c}{ Source } & Citations & Total Link Strength \\
\hline 1 & Journal of Marketing & 668 & 28,800 \\
2 & Journal of Marketing Research & 324 & 14,983 \\
3 & Journal of Business Research & 276 & 8372 \\
4 & Journal of the Academy of Marketing Science & 258 & 12,984 \\
5 & European Journal of Marketing & 214 & 12,070 \\
6 & Journal of Travel E Tourism Marketing & 199 & 1258 \\
7 & Journal of Interactive Marketing & 195 & 5029 \\
8 & Harvard Business Review & 188 & 4582 \\
9 & Industrial Marketing Management & 185 & 5533 \\
10 & Journal of Retailing & 176 & 5596 \\
\hline
\end{tabular}

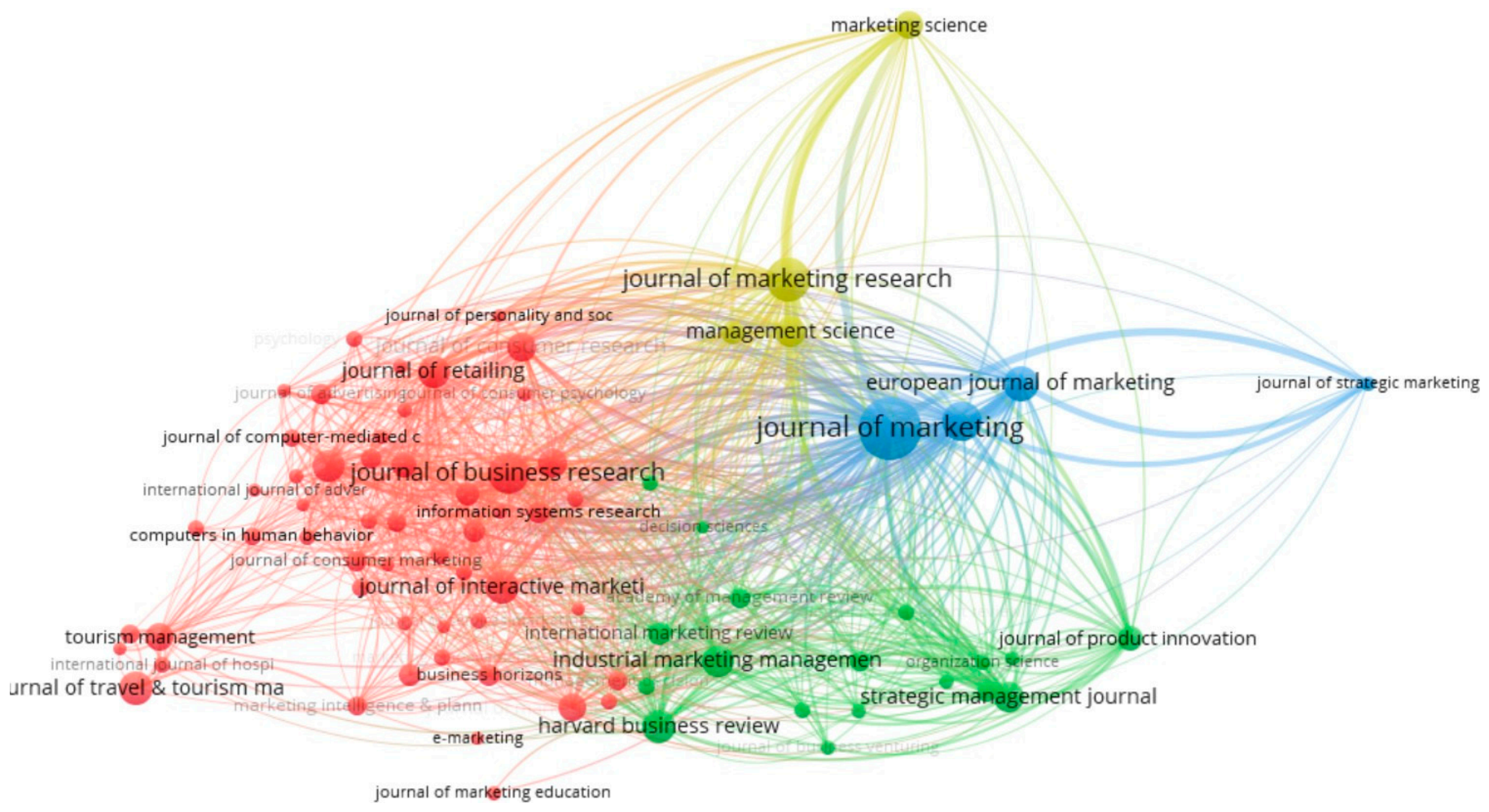

Figure 4. Co-citation of the top ten journals.

\subsection{The Most Productive Authors in Electronic Marketing}

In order to see who published their works on electronic marketing most frequently, we present the results in Table 6. El-Gohary H. topped the list with 7 publications having 190 citations. Cui G. was second with 4 publications having 294 citations. Shaltoni A.M. was third with 4 publications having 46 citations, Ahuja V. was fourth with 4 publications having 0 citations, while Guo X. was fifth with 3 publication having 289 citations. Yan R. was sixth with 3 publication having 155 citations, Vlachopoulou M. was seventh with 3 publication having 67 citations, Tsekouropoulos G. was eighth with 3 publications having 58 citations, Andreopoulou Z. was ninth with 3 publications having 58 citations, and finally, Chong W.K. was tenth with 3 publications having 42 citations. 
Table 6. The most productive authors in electronic marketing.

\begin{tabular}{|c|c|c|c|c|}
\hline Rank & Author & Affiliation & No. of Papers & Citations \\
\hline 1 & El-Gohary H. & $\begin{array}{l}\text { Qatar University, College of Business and Economics, Doha, } \\
\text { Qatar }\end{array}$ & 7 & 190 \\
\hline 2 & Cui G. & $\begin{array}{l}\text { Lingnan University, Hong Kong, Faculty of Business, } \\
\text { Hong Kong, Hong Kong }\end{array}$ & 4 & 294 \\
\hline 3 & Shaltoni A.M. & $\begin{array}{l}\text { Alfaisal University, College of Business, Riyadh, Saudi } \\
\text { Arabia }\end{array}$ & 4 & 46 \\
\hline 4 & Ahuja V. & $\begin{array}{l}\text { Amity University, Noida, Amity Business School, Noida, } \\
\text { India }\end{array}$ & 4 & 0 \\
\hline 5 & Guo X. & $\begin{array}{l}\text { Carl H. Lindner College of Business, Cincinnati, } \\
\text { United States }\end{array}$ & 3 & 289 \\
\hline 6 & Yan R. & Texas A\&M University, College Station, United States & 3 & 155 \\
\hline 7 & Vlachopoulou M. & $\begin{array}{l}\text { Panepistimion Makedonias, Department of Applied } \\
\text { Informatics, Thessaloniki, Greece }\end{array}$ & 3 & 67 \\
\hline 8 & Tsekouropoulos G. & $\begin{array}{l}\text { Alexander Technological Educational Institute of } \\
\text { Thessaloniki, Thessaloniki, Greece }\end{array}$ & 3 & 58 \\
\hline 9 & Andreopoulou Z. & $\begin{array}{l}\text { Aristotle University of Thessaloniki, Laboratory of Forest } \\
\text { Informatics, Thessaloniki, Greece }\end{array}$ & 3 & 58 \\
\hline 10 & Chong W.K. & $\begin{array}{l}\text { Xi'an Jiaotong-Liverpool University, International Business } \\
\text { School Suzhou, Suzhou, China }\end{array}$ & 3 & 42 \\
\hline 11 & Waheed A. & $\begin{array}{l}\text { University of Management and Technology Lahore, Lahore, } \\
\text { Pakistan }\end{array}$ & 3 & 21 \\
\hline 12 & Fedorko R. & $\begin{array}{l}\text { University of Presov in Presov, Faculty of Management, } \\
\text { Presov-Lubotice, Slovakia }\end{array}$ & 3 & 15 \\
\hline 13 & Bac`ík R. & $\begin{array}{l}\text { University of Presov in Presov, Faculty of Management, } \\
\text { Martin, Slovakia }\end{array}$ & 3 & 15 \\
\hline 14 & Štefko R. & $\begin{array}{l}\text { University of Presov in Presov, Faculty of Management, } \\
\text { Presov-Lubotice, Slovakia }\end{array}$ & 3 & 13 \\
\hline 15 & Sürer A. & $\begin{array}{l}\text { Gaziantep Üniversitesi, Department of International Trade } \\
\text { and Logistics, Gaziantep, Turkey }\end{array}$ & 3 & 7 \\
\hline
\end{tabular}

\subsection{The Most-Cited Publication}

To indicate the most-cited source, in this section, we recognized the most-cited publications. To this end, we relied upon the statistics from the Scopus databank. We present the results in Table 7. As was stated in the Methods section, we typed certain keywords (e.g., electronic marketing, eM, and e-marketing) in the search option of the Scopus database and selected the "Article title, Abstract, Keywords" options. This provided us a list of all those publications which had electronic marketing in their titles, abstracts, or keywords.

A paper written by Hennig-Thurau T. and Walsh G. in 2003 titled "Electronic word-ofmouth: Motives for and consequences of reading customer articulations on the internet" was the most productive publication with 451 citations. The second-most-cited publication was authored by Cheung C.M.K. and Lee M.K.O. in 2012, and this publication received 432 citations.

The third-most-cited paper's title was "Patterns of cooperation during new product development among marketing, operations and R\&D: Implications for project performance", authored by Olson E.M., Walker Jr. O.C., Ruekert R.W., and Bonner J.M. in 2001, and this paper received 309 citations. 
Table 7. The most cited publication.

\begin{tabular}{|c|c|c|c|c|c|}
\hline Rank & Authors & Publication Title & Year & Source Title & Citations \\
\hline 1 & $\begin{array}{l}\text { Hennig-Thurau T., } \\
\text { Walsh G. [37] }\end{array}$ & $\begin{array}{l}\text { Electronic word-of-mouth: Motives } \\
\text { for and consequences of reading } \\
\text { customer articulations on the internet }\end{array}$ & 2003 & $\begin{array}{l}\text { International Journal of } \\
\text { Electronic Commerce }\end{array}$ & 451 \\
\hline 2 & $\begin{array}{l}\text { Cheung C.M.K., Lee } \\
\text { M.K.O. [38] }\end{array}$ & $\begin{array}{l}\text { What drives consumers to spread } \\
\text { electronic word of mouth in online } \\
\text { consumer-opinion platforms }\end{array}$ & 2012 & $\begin{array}{l}\text { Decision Support } \\
\text { Systems }\end{array}$ & 432 \\
\hline 3 & $\begin{array}{l}\text { Olson E.M., Walker Jr. } \\
\text { O.C., Ruekert R.W., } \\
\text { Bonner J.M. [39] }\end{array}$ & $\begin{array}{l}\text { Patterns of cooperation during new } \\
\text { product development among } \\
\text { marketing, operations and R\&D: } \\
\text { Implications for project performance }\end{array}$ & 2001 & $\begin{array}{l}\text { Journal of Product } \\
\text { Innovation Management }\end{array}$ & 309 \\
\hline 4 & $\begin{array}{l}\text { Cui G., Lui H.-K., Guo } \\
\text { X. [40] }\end{array}$ & $\begin{array}{l}\text { The effect of online consumer reviews } \\
\text { on new product sales }\end{array}$ & 2012 & $\begin{array}{l}\text { International Journal of } \\
\text { Electronic Commerce }\end{array}$ & 288 \\
\hline 5 & $\begin{array}{l}\text { Chang H.H., Wang } \\
\text { Y.-H., Yang W.-Y. [41] }\end{array}$ & $\begin{array}{l}\text { The impact of e-service quality, } \\
\text { customer satisfaction and loyalty on } \\
\text { e-marketing: Moderating effect of } \\
\text { perceived value }\end{array}$ & 2009 & $\begin{array}{l}\text { Total Quality } \\
\text { Management and } \\
\text { Business Excellence }\end{array}$ & 225 \\
\hline 6 & $\begin{array}{l}\text { Kaplan A.M., Haenlein } \\
\text { M. [42] }\end{array}$ & $\begin{array}{l}\text { The early bird catches the news: Nine } \\
\text { things you should know about } \\
\text { micro-blogging }\end{array}$ & 2011 & Business Horizons & 212 \\
\hline 7 & $\begin{array}{l}\text { Hassanein K., Head } \\
\text { M. [43] }\end{array}$ & $\begin{array}{l}\text { The impact of infusing social } \\
\text { presence in the web interface: An } \\
\text { investigation across product types }\end{array}$ & 2005 & $\begin{array}{l}\text { International Journal of } \\
\text { Electronic Commerce }\end{array}$ & 201 \\
\hline 8 & $\begin{array}{l}\text { Liebermann Y., } \\
\text { Stashevsky S. [44] }\end{array}$ & $\begin{array}{l}\text { Perceived risks as barriers to Internet } \\
\text { and e-commerce usage }\end{array}$ & 2002 & $\begin{array}{l}\text { Qualitative Market } \\
\text { Research: An } \\
\text { International Journal }\end{array}$ & 188 \\
\hline 9 & $\begin{array}{l}\text { Baloglu S., Pekcan } \\
\text { Y.A. [45] }\end{array}$ & $\begin{array}{l}\text { The website design and Internet site } \\
\text { marketing practices of upscale and } \\
\text { luxury hotels in Turkey }\end{array}$ & 2006 & Tourism Management & 174 \\
\hline 10 & El-Gohary H. [1] & $\begin{array}{l}\text { Factors affecting E-Marketing } \\
\text { adoption and implementation in } \\
\text { tourism firms: An empirical } \\
\text { investigation of Egyptian small } \\
\text { tourism organisations }\end{array}$ & 2012 & Tourism Management & 129 \\
\hline 11 & Constantinides E. [46] & $\begin{array}{l}\text { The Marketing Mix Revisited: } \\
\text { Towards the 21st Century Marketing }\end{array}$ & 2006 & $\begin{array}{l}\text { Journal of Marketing } \\
\text { Management }\end{array}$ & 124 \\
\hline 12 & $\begin{array}{l}\text { Kalyanam K., } \\
\text { McIntyre S. [47] }\end{array}$ & $\begin{array}{l}\text { The E-marketing mix: A contribution } \\
\text { of the E-tailing wars }\end{array}$ & 2002 & $\begin{array}{l}\text { Journal of the Academy } \\
\text { of Marketing Science }\end{array}$ & 105 \\
\hline 13 & Wan H.A. [48] & $\begin{array}{l}\text { Opportunities to enhance a } \\
\text { commercial website }\end{array}$ & 2000 & $\begin{array}{l}\text { Information and } \\
\text { Management }\end{array}$ & 103 \\
\hline 14 & $\begin{array}{l}\text { Taylor D.G., Strutton } \\
\text { D. [49] }\end{array}$ & $\begin{array}{l}\text { Has e-marketing come of age? } \\
\text { Modeling historical influences on } \\
\text { post-adoption era Internet consumer } \\
\text { behaviors }\end{array}$ & 2010 & $\begin{array}{l}\text { Journal of Business } \\
\text { Research }\end{array}$ & 101 \\
\hline 15 & $\begin{array}{l}\text { Coviello N., Milley R., } \\
\text { Marcolin B. [50] }\end{array}$ & $\begin{array}{l}\text { Understanding IT-enabled } \\
\text { interactivity in contemporary } \\
\text { marketing }\end{array}$ & 2001 & $\begin{array}{l}\text { Journal of Interactive } \\
\text { Marketing }\end{array}$ & 101 \\
\hline
\end{tabular}

\section{Conclusions}

The use of bibliometrics helps to identify and classify scientific activity in a particular field, such as in journals, and serves as a tool for getting an idea of the key themes or trends in a given journal or academic field. The bibliometric research of a sole publication in a certain era of time offers valued evidence for seeing the growth and features of its systematic creation. Based on the Scopus results, this paper offers a bibliometric overview of electronic marketing investigation.

The aim of this research was to identify the productivity (number of articles) and degree of impact of the publishing institutions as a result, reacting to the need for a thorough examination of their scientific performance. According to the findings, the 
number of documents published each year has risen steadily over time. Simultaneously, as the number of documents has grown, so has the number of citations earned by articles, demonstrating the recognition of electronic marketing as a field of research. The 438 papers published and indexed in Scopus had a total of 6173 citations. The study obtained more than half of its citations in the last three years of the period from 2000 to 2019. This article, like every other research project, has some drawbacks that should be considered. One of these drawbacks, for example, is author affiliation, which can change over time, resulting in several papers by the same author having different affiliations. The findings, on the other hand, paint a picture of the current characteristics of electronic marketing research, which are expected to evolve over time. As a result, it is a good idea to stay up to date on emerging trends. Despite these flaws, this bibliometric review highlights the most critical developments in electronic marketing, which could be beneficial to both prospective authors and the media audiences interested in electronic marketing.

\section{Future Directions}

The scope of e-marketing is not restricted to an exact area. Nevertheless, it is a valued system to convey the product information inside a country as well as across a country [51].

The researchers may consider more studies in the future related to e-marketing as summarized below:

- The future studies might be conducted using an empirical approach to ensure the validity and significance of electronic marketing within deviser contexts globally;

- A comprehensive study could be expanded with different domains, such as from business-to-consumer or business-to-government, to confirm the significance of such developing communication channels in marketing practices and to contribute in the respective literature;

- The future studies could be regarded toward other geographical locations with distinct variables;

- The future studies might be expanded with the moderating effects of different variables, such as age, gender, social class, or any environmental or political factor, to ensure a moderating role between electronic marketing and the remaining aspects. In the past, a few studies of e-marketing adopted moderating factors. Therefore, by doing so, researchers could better understand the relational strength of e-marketing;

- The future studies might be conducted to develop comprehensive scales for e-marketing, which are still missing in the literature;

- How e-marketing could be an effective tool to transmit product or service messages, especially in developing nations, could be an important question to address in the future;

- What are the most effective antecedents of e-marketing could be another question for future consideration;

- Determining which is the most effective sub-tool of e-marketing for global communications that could be part of future investigations;

- How electronic marketing can create value for distinct stakeholders could also be a question for consideration in the future;

- The future work might consider publications that were published in other languages to understand the real picture of e-marketing research among scholars worldwide;

- When analyzing the literature, it became clear that electronic marketing studies have used a mix of qualitative and quantitative methods. However, in the author's opinion, there is no such thing as an ideal research methodology or procedure. Since each approach or method has its own set of disadvantages and limitations, a researcher must choose the most suitable research methodology and method for his study. In this regard, the author strongly advises using a triangulation method when conducting future research in the field of e-marketing. Researchers can use all three types of triangulation (data, method, and methodological triangulation) or only one of them, in which quantitative and qualitative data can be obtained using a hybrid research 
approach, such as a survey and case study strategy, as well as appropriate research methods, such as questionnaires and interviews, to answer various levels of potential studies.

Author Contributions: All authors contributed equally in the realization of the manuscript. All authors have read and agreed to the published version of the manuscript.

Funding: Fanchen Meng acknowledges the financial support from the Nation Natural Science Foundation of China (grant number 71972013). Muhammad Farrukh acknowledges the financial support from the ILMA university.

Institutional Review Board Statement: Not applicable.

Informed Consent Statement: Not applicable.

Data Availability Statement: The data presented in this study are available on request from the corresponding author.

Conflicts of Interest: The authors declare no conflict of interest.

\section{References}

1. El-Gohary, H. Factors affecting E-Marketing adoption and implementation in tourism firms: An empirical investigation of Egyptian small tourism organisations. Tour. Manag. 2012, 33, 1256-1269. [CrossRef]

2. Waheed, A.; Jianhua, Y. Achieving consumers' attention through emerging technologies. Balt. J. Manag. 2018, 13, 209-235. [CrossRef]

3. Brodie, R.J.; Winklhofer, H.; Coviello, N.E.; Johnston, W.J. Is e-marketing coming of age? An examination of the penetration of e-marketing and firm performance. J. Interact. Mark. 2007, 21, 2-21. [CrossRef]

4. Coviello, N.E.; Brodie, R.J.; Brookes, R.W.; Palmer, R.A. Assessing the Role of e-Marketing in Contemporary Marketing Practice. J. Mark. Manag. 2003, 19, 857-881. [CrossRef]

5. Gilmore, A.; Gallagher, D.; Henry, S. E-marketing and SMEs: Operational lessons for the future. Eur. Bus. Rev. 2007, 19, 234-247. [CrossRef]

6. Saura, J.R. Using Data Sciences in Digital Marketing: Framework, methods, and performance metrics. J. Innov. Knowl. 2021, 6, 92-102. [CrossRef]

7. Saura, J.R.; Ribeiro-Soriano, D.; Palacios-Marqués, D. From user-generated data to data-driven innovation: A research agenda to understand user privacy in digital markets. Int. J. Inf. Manag. 2021, 102331. [CrossRef]

8. Scharl, A.; Dickinger, A.; Murphy, J. Diffusion and success factors of mobile marketing. Electron. Commer. Res. Appl. 2005, 4, 159-173. [CrossRef]

9. Neill, W.D.; Richard, J.E. Intranet Portals: Marketing and Managing Individuals' Acceptance and Use. Australas. Mark. J. 2012, 20, 147-157. [CrossRef]

10. Saura, J.R.; Palos-Sanchez, P.; Herráez, B.R. Digital Marketing for Sustainable Growth: Business Models and Online Campaigns Using Sustainable Strategies. Sustainability 2020, 12, 1003. [CrossRef]

11. Mathews, S.; Bianchi, C.; Perks, K.J.; Healy, M.; Wickramasekera, R. Internet marketing capabilities and international market growth. Int. Bus. Rev. 2016, 25, 820-830. [CrossRef]

12. Broadus, R.N. Toward a definition of "bibliometrics". Scientometrics 1987, 12, 373-379. [CrossRef]

13. Matos, N.; Correia, M.; Saura, J.; Reyes-Menendez, A.; Baptista, N. Marketing in the Public Sector-Benefits and Barriers: A Bibliometric Study from 1931 to 2020. Soc. Sci. 2020, 9, 168. [CrossRef]

14. Shahzad, I.A.; Farrukh, M.; Wu, Y.; Trunk, N. Human systems management: A retrospective of 40 years. Hum. Syst. Manag. 2021, 40, 15-30. [CrossRef]

15. Ritter, B.A. The 100 Most Cited Articles in Business and Management Education Research. Organ. Manag. J. 2015, 12, 153. [CrossRef]

16. Heyduk, R.G.; Fenigstein, A. Influential works and authors in psychology: A survey of eminent psychologists. Am. Psychol. 1984, 39, 556-559. [CrossRef]

17. Pasadeos, Y.; Renfro, R.B.; Hanily, M.L. Influential Authors and Works of the Public Relations Scholarly Literature: A Network of Recent Research. J. Public Relat. Res. 1999, 11, 29-52. [CrossRef]

18. Bonner, S.E.; Hesford, J.W.; Van Der Stede, W.A.; Young, S.M. The most influential journals in academic accounting. Account. Organ. Soc. 2006, 31, 663-685. [CrossRef]

19. Cancino, C.A.; Merigó, J.M.; Coronado, F.C. A bibliometric analysis of leading universities in innovation research. J. Innov. Knowl. 2017, 2, 106-124. [CrossRef]

20. Farrukh, M.; Javed, S.; Raza, A.; Lee, J.W.C. Twenty years of green innovation research: Trends and way forward. World J. Entrep. Manag. Sustain. Dev. 2021. [CrossRef] 
21. Saura, J.R.; Palacios-Marqués, D.; Iturricha-Fernández, A. Ethical design in social media: Assessing the main performance meas-urements of user online behavior modification. J. Bus. Res. 2021, 129, 271-281. [CrossRef]

22. Ribeiro-Navarrete, S.; Saura, J.R.; Palacios-Marqués, D. Towards a new era of mass data collection: Assessing pandemic surveil-lance technologies to preserve user privacy. Technol. Forecast. Soc. Chang. 2021, 167, 120681. [CrossRef]

23. Farrukh, M.; Shahzad, I.A.; Meng, F.; Wu, Y.; Raza, A. Three decades of research in the technology analysis \& strategic management: A bibliometrics analysis. Technol. Anal. Strateg. Manag. 2020, 1-17. [CrossRef]

24. Farrukh, M.; Raza, A.; Meng, F.; Wu, Y. CMS at 13: A retrospective of the journey. Chin. Manag. Stud. 2021. [CrossRef]

25. Nawaz, K.; Aslam, T.; Saeed, H.A. A Bibliometric Analysis of International Journal of Sports Marketing \& Sponsorship. Int. J. Bus. Psychol. 2020, 2, 45-60.

26. Gu, Z.; Meng, F.; Farrukh, M. Mapping the Research on Knowledge Transfer: A Scientometrics Approach. IEEE Access 2021, 9 , 34647-34659. [CrossRef]

27. Nawaz, K.; Saeed, H.A.; Sajeel, T.A. Covid-19 and the State of Research from the Perspective of Psychology. Int. J. Bus. Psychol. 2020, 2, 35-44.

28. Cancino, C.A.; Merigó, J.M.; Urbano, D.; Amorós, J.E. Evolution of the entrepreneurship and innovation research in Ibero-America between 1986 and 2015. J. Small Bus. Manag. 2020,1-31. [CrossRef]

29. Bar-Ilan, J. Informetrics at the beginning of the 21st century-A review. J. Inf. 2008, 2, 1-52. [CrossRef]

30. Bonilla, C.A.; Merigó, J.M.; Torres-Abad, C. Economics in Latin America: A bibliometric analysis. Scientometrics 2015, 105, 1239-1252. [CrossRef]

31. Amiguet, L.; Lafuente, G.; Kydland, A.M.; Finn, E.; Lindahl, M.; Jose, M. One Hundred Twenty-Five Years of the Journal of Political Economy: A Bibliometric Overview. J. Polit. Econ. 2017, 6, 125.

32. Martínez-López, F.J.; Merigó, J.M.; Valenzuela-Fernández, L.; Nicolás, C. Fifty years of the European Journal of Marketing: A bibliometric analysis. Eur. J. Mark. 2018, 52, 439-468. [CrossRef]

33. Merigó, J.M.; Cancino, C.A.; Coronado, F.; Urbano, D. Academic research in innovation: A country analysis. Scientometrics 2016, 108, 559-593. [CrossRef]

34. van Eck, N.J.; Waltman, L. Software survey: VOSviewer, a computer program for bibliometric mapping. Scientometrics 2010, 84, 523-538. [CrossRef]

35. Kessler, M.M. Bibliographic coupling between scientific papers. Am. Doc. 1963, 14, 10-25. [CrossRef]

36. Small, H. Co-citation in the scientific literature: A new measure of the relationship between two documents. J. Am. Soc. Inf. Sci. 1973, 24, 265-269. [CrossRef]

37. Hennig-Thurau, T.; Walsh, G.; Walsh, G. Electronic Word-of-Mouth: Motives for and Consequences of Reading Customer Articu-lations on the Internet. Int. J. Electron. Commer. 2003, 8, 51-74. [CrossRef]

38. Cheung, C.; Lee, M. What drives consumers to spread electronic word of mouth in online consumer-opinion platforms. Decis. Support Syst. 2012, 53, 218-225. [CrossRef]

39. Olson, E.M.; Walker, O.C.; Ruekerf, R.W.; Bonnerd, J.M. Patterns of cooperation during new product development among mar-keting, operations and R\&D: Implications for project performance. J. Prod. Innov. Manag. 2001, 18, $258-271$.

40. Cui, G.; Lui, H.-K.; Guo, X. The Effect of Online Consumer Reviews on New Product Sales. Int. J. Electron. Commer. 2012, 17, 39-58. [CrossRef]

41. Chang, H.H.; Wang, Y.-H.; Yang, W.-Y. The impact of e-service quality, customer satisfaction and loyalty on e-marketing: Moderating effect of perceived value. Total Qual. Manag. 2009, 20, 423-466. [CrossRef]

42. Kaplan, A.M.; Haenlein, M. The early bird catches the news: Nine things you should know about micro-blogging. Bus. Horiz. 2011, 54, 105-113. [CrossRef]

43. Hassanein, K.; Head, M. The Impact of Infusing Social Presence in the Web Interface: An Investigation Across Product Types. Int. J. Electron. Commer. 2005, 10, 31-55. [CrossRef]

44. Liebermann, Y.; Stashevsky, S. Perceived risks as barriers to Internet and e-commerce usage. Qual. Mark. Res. Int. J. 2002, 5, 291-300. [CrossRef]

45. Baloglu, S.; Pekcan, Y.A. The website design and Internet site marketing practices of upscale and luxury hotels in Turkey. Tour. Manag. 2006, 27, 171-176. [CrossRef]

46. Constantinides, E. The Marketing Mix Revisited: Towards the 21st Century Marketing. J. Mark. Manag. 2006, 22, 407-438. [CrossRef]

47. Kalyanam, K.; McIntyre, S. The E-Marketing Mix: A Contribution of the E-Tailing Wars. J. Acad. Mark. Sci. 2002, 30, 487-499. [CrossRef]

48. Wan, H.A. Opportunities to enhance a commercial website. Inf. Manag. 2000, 38, 15-21. [CrossRef]

49. Taylor, D.G.; Strutton, D. Has e-marketing come of age? Modeling historical influences on post-adoption era Internet consumer behaviors. J. Bus. Res. 2010, 63, 950-956. [CrossRef]

50. Coviello, N.; Milley, R.; Marcolin, B. Understanding IT-enabled interactivity in contemporary marketing. J. Interact. Mark. 2001, 15, 18-33. [CrossRef]

51. Loane, S.; McNaughton, R.B.; Bell, J. The Internationalization of Internet-Enabled Entrepreneurial Firms: Evidence from Europe and North America. Can. J. Adm. Sci. 2009, 21, 79-96. [CrossRef] 